\title{
UPAYA MENINGKATKAN MINAT DAN KEMAMPUAN MENYUSUN RPP PADA GURU KELAS MELALUI SUPERVISI AKADEMIK
}

\author{
Sutarman \\ UPT Dinas Pendidikan Kabupaten Wonogiri \\ endang3winarni@gmail.com
}

\begin{abstract}
Abstrak
Penelitian ini bertujuan untuk meningkatkan minat dan kemampuan guru kelas dalam menyusun RPP. Tindakan yang diberikan peneliti dalam penelitian yaitu dengan menerapkan metode supervise akademik bagi guru. Penelitian merupakan jenis penelitian tindakan atau Action Research. Penelitian ini dilaksanakan pada sepuluh Sekolah Dasar Binaan Suraseranggen Unit Pelayanan Teknis (UPT) Dinas Pendidikan Kecamatan Slogohimo Kabupaten Wonogiri. Penelitian dilaksanakan pada Semester I Tahun Pelajaran 2014-2015, Subjek Penelitian Tindakan Sekolah ini adalah dua puluh orang guru kelas V dan VI. Objek penelitian adalah minat dan kemampuan guru sekolah dasar Binaan Suraseranggen dalam menyusun Rencana Pelaksanaan Pembelajaran. Penelitian tindakan ini dilaksanakan dalam dua siklus yaitu siklus I dan siklus II. Hasil penelitian ini yaitu Pelaksanaan supervisi akademik yang dilakukan Pengawas sudah mampu meningkatkan minat dan kemampuan guru di Sekolah Dasar Binaan Suraseranggen Unit Pelayanan Teknis (UPT) Dinas Pendidikan Kecamatan Slogohimo Kabupaten Wonogiri Semester 1 Tahun Pelajaran 2014/2015 dalam menyusun Rencana Pelaksanaan Pembelajaran, sesuai dengan indikator kinerja yang telah ditetapkan.
\end{abstract}

Kata Kunci : Minat, Kemampuan, RPP, Supervisi Akademik.

\begin{abstract}
This study aims to increase the interest and ability of classroom teachers in preparing lesson plans. The action that the researcher gave in the research was by applying the academic supervision method for the teacher. Research is a type of action research or Action Research. This research was conducted at ten elementary schools that were built by Suraseranggen Technical Service Unit (UPT) of the Education Office of Slogohimo District, Wonogiri Regency. The research was conducted in Semester I of the 20142015 academic year, the subjects of this school action research were twenty grade V and VI teachers. The object of research is the interest and ability of the Suraseranggen-assisted elementary school teachers in compiling a Learning Implementation Plan. This action research was conducted in two cycles, namely cycle I and cycle II. The result of this research is that the implementation of academic supervision carried out by supervisors has been able to increase the interest and ability of teachers in the Suraseranggen Primary Schools Technical Service Unit (UPT) of the Slogohimo District Education Office, Wonogiri Regency Semester 1 of the 2014/2015 Academic Year in compiling a Learning Implementation Plan, according to the indicators. performance that has been set.
\end{abstract}

Keywords: Interests, Abilities, RPP, Academic Supervision.

\section{PENDAHULUAN}

Mengajar adalah tugas guru paling utama sebagai tenaga profesional, sebelum mengajar guru diwajibkan membuat Rencana Pelaksanaan Pembelajaran (RPP), hal itu sudah diamanatkan sejak Kurikulum 1975 sampai sekarang. Diharapkan dengan membuat RPP tujuan pembelajaran akan tercapai sesuai dengan yang direncanakan untuk mencapai tujuan pendidikan nasional. Tetapi kenyataan sejak dahulu sampai sekarang permasalahan menyusun RPP selalu menjadi hambatan dalam guru akan mengajar, sebelum ada komputer sampai sekarang dengan teknologi yang maju pun tetap saja RPP menjadi kendala utama setiap guru akan mengajar. Sebelum ada komputer guru tidak membuat RPP dengan alasan enggan menulis RPP karena banyak menyita waktu untuk menulis, sekarang dengan adanya komputer juga enggan membuat RPP sendiri sebagian 
besar hanya copy paste punya teman atau download di internet tanpa mau mengubah menyesuaikan dengan kondisi di sekolahnya.

Penyusunan RPP belum sesuai dengan Permendiknas No.41 Tahun 2007 tentang standar proses, yang mengamanatkan dalam kegiatan inti pembelajaran terdapat tiga tahapan yaitu Eksplorasi, Elaborasi dan Konfirmasi (EEK) (Undang Undang RI No: 20 Sistem Pendidikan Nasional, 2003). Alasan lain yang sering dijumpai adalah karena sudah berpengalaman mengajar bertahun-tahun para guru merasa dirinya sudah dapat mengajar dengan baik, mekipun tidak dapat menunjukkan alasan yang mendasari asumsi tersebut. Seringkali asumsi tersebut justru menyesatkan, menurunkan kreatifitas, sehingga banyak guru mengajar ala kadarnya dan tanpa arah yang jelas. Buku sumber yang di gunakan dalam RPP juga tidak disebutkan secara spesifik mengacu pada etika intelektual.

Permasalahan RPP tersebut di atas juga terjadi pada Sekolah dasar Binaan Suraseranggen Unit Pelayanan Teknis (UPT) Dinas Pendidikan Kecamatan Slogohimo Kabupaten Wonogiri . Dari hasil penilaian RPP sepuluh guru rata-rata hanya memperoleh nilai 56 yang berarti kurang dan masih jauh dari apa yang diharapkan. Hal itu disebabkan juga karena belum adanya supervisi akademik oleh pengawas sekolah. Sebenarnya kegiatan merencanakan dan melaksanakan pembelajaran merupakan salah satu tugas dan kewajiban guru yang sudah diatur dalam Peraturan Menteri Pendayagunaan dan Aparatur Pemerintah nomor 16 tahun 2009. Salah satu kompetensi yang dipersyaratkan dalam standar kompetensi dan kualifikasi akademik guru dalam Peraturan Menteri Pendidikan Nasional tahun 2007 juga mempersyaratkan bahwa guru harus mempunyai kompetensi dalam menyusun rancangan kegiatan pembelajaran dan melaksanakan pembelajaran.

Permendiknas nomor 41 tahun 2007 tentang Standar proses pembelajaran untuk Pendidikan Dasar dan Menengah yang menyebutkan bahwa setiap guru wajib menyusun RPP dan menggunakannya sebagai pedoman pelaksanaan pembelajaran. Penyusunan Rencana Pelaksanaan Pembelajaran yang baik akan sangat mempengaruhi terhadap perilaku pembelajaran yang dilakukan oleh guru. Kemampuan menyusun perencanaan pembelajaran dan melaksanakan pembelajaran merupakan bagian dari kompetensi pedagogik guru yang harus dimiliki oleh guru untuk bisa melakukan pembelajaran yang mendidik sebagai persyaratan guru profesional.

Dengan melihat tugas dan kewajiban guru dalam pembelajaran tentunya dibutuhkan guru yang profesional dalam mengelola pembelajaran. Pembinaan dalam rangka peningkatan profesionalisme guru sudah banyak dilakukan oleh pemerintah baik melalui penataran, pelatihan, workshop, seminar, dan bentuk pertemuan ilmiah yang lain. Pada kenyataan masih terdapat beberapa kendala yang membutuhkan pembinaan dan pembimbingan secara berkelanjutan oleh pihak terkait. Realitas dan kondisi di lapangan dengan berdasarkan hasil pengamatan penulis bahwa perencanaan pembelajaran yang dilaksanakan di sekolah ternyata kemampuan guru dalam menyusun RPP masih belum baik, belum baiknya RPP yang disusun oleh para guru tersebut adalah disebabkan oleh beberapa hal diantaranya yaitu dikarenakan pemahaman guru terhadap cara penyusunan RPP yang masih sangat kurang di antaranya adalah ketidaksesuaian indikator dengan kegiatan pembelajaran, ketidaksesuaian indikator dengan alokasi waktu, ketidaksesuaian indikator dengan metode dan media, ketidaksesuaian 
indikator dengan instrumen penilaian dan proses penyusunan perencanaan dan pelaksanaan kegiatan pembelajaran yang masih kurang baik yang terlihat dari masih banyak ditemukan bahwa guru-guru dalam merencanakan pembelajaran utamanya dalam menyusun RPP hanya mengadopsi yang sudah ada tanpa mengadaptasi disesuaikan dengan kondisi peserta didik sehingga terlihat jelas sekali bahwa dokumen perencanaan pembelajaran disiapkan hanya untuk memenuhi kepentingan birokratis tanpa diketahui makna dan manfaatnya.

Permasalahan ketidakmampuan guru dalam memaksimalkan aktivitas belajar siswa juga terlihat dari ketidakmampuan guru dalam pengalaman belajar yang sesuai untuk mencapai tujuan pembelajaran yang diampu mengakibatkan kegagalan guru dalam meningkatkan hasil belajar siswa. Perkembangan zaman mengharuskan guru untuk terus berkembang dan meningkatkan kompetensinya. (Nurgiansah \& Pringgowijoyo, 2020). Selain itu permasalahan ketidakmampuan guru dalam menerapkan berbagai pendekatan, strategi, metode, dan teknik pembelajaran yang mendidik dalam mata pelajaran yang diampu menjadi penyebab terjadinya hasil pembelajaran yang belum menunjukkan hasil belajar yang maksimal terlihat dari keberhasilan dalam persentasi ketuntasan hasil belajar. Dalam hal pelaksanaan pembelajaran yang merupakan implementasi dari RPP masih banyak muncul masalah di antaranya adalah:1) keterampilan guru dalam membuka pelajaran yang masih kurang baik, 2) kemampuan guru dalam melaksanakan kegiatan inti pembelajaran, 3) kemampuan menilai sesuai dengan tujuan pembelajaran, 4) kemampuan guru dalam menutup pelajaran, 5) Guru masih berperan sebagai pusat pembelajaran, dan
6) tidak ada perhatian guru terhadap siswa secara individu.

Apabila situasi pembelajaran yang demikian dibiarkan dalam waktu yang berlangsung lama dapat menyebabkan penurunan minat belajar siswa dalam mengikuti pembelajaran khususnya matap elajaran sehingga aktivitas belajar siswa menjadi rendah yang dimungkinkan akan berdampak pada hasil belajar siswa yang rendah. Rendahnya minat dan kemampuan guru Sekolah dasar Binaan Suraseranggen Unit Pelayanan Teknis (UPT) Dinas Pendidikan Kecamatan Slogohimo Kabupaten Wonogiri dalam menyusun Rencana Pelaksanaan Pembelajaran perlu segera dipecahkan. Melalui supervisi akademik diharapkan para guru lebih professional dalam menyusun RPP, guru akan lebih bersemangat dalam membuat RPP karena jika ada kesulitan bisa memperoleh bantuan dalam pertemuan dengan peneliti.

Peneliti selaku supervisor perlu mengadakan pembinaan akademik. Pembinaan dilaksanakan dalam dua tahapan, yaitu secara klasikal dan berpasangan. Pembinaan klasikal yaitu pembinaan umum dikuti oleh seluruh guru secara bersama - sama. Pembinaan berpasangan dilakukan kepada dua orang guru secara bersama. Tindakan pembinaan dilakukan untuk meningkatkan minat dan kemampuan menyusun Rencana Pelaksanaan Pembelajaran bagi guru Sekolah dasar Binaan Suraseranggen Unit Pelayanan Teknis (UPT) Dinas Pendidikan Kecamatan Slogohimo Kabupaten Wonogiri.

\section{METODE PENELITIAN}

Penelitian dilaksanakan di Sekolah Dasar Binaan Suraseranggen Unit Pelayanan Teknis (UPT) Dinas Pendidikan Kecamatan Slogohimo Kabupaten Wonogiri. Alasan pemilihan tempat penelitian yaitu karena peneliti adalah 
pengawas sekolah pada wilayah tersebut, sehingga memudahkan proses penelitian, sedangkan nama Suraseranggen diambil dari suku kata dabin binaan terdiri dari SDN 1 dan 2 Sukaboyo, SDN 1, 2, dan 3 Randusari, SDN 1 dan 2 Setren, SDN 1 dan 2 Karang serta SDN 1 Klunggen. Penelitian dilaksanakan pada Semester I Tahun Pelajaran 2014-2015, selama lima bulan, dimulai bulan Juli dan berakhir bulan November 2014. Subjek Penelitian Tindakan Sekolah ini adalah guru guru sekolah dasar Binaan Suraseranggen Unit Pelayanan Teknis (UPT) Dinas Pendidikan Kecamatan Slogohimo Kabupaten Wonogiri, yang berjumlah dua puluh orang guru dari 10 sekolah dasar.

Objek dari penelitian ini yaitu 1) Minat guru sekolah dasar Binaan Suraseranggen Unit Pelayanan Teknis (UPT) Dinas Pendidikan Kecamatan Slogohimo Kabupaten Wonogiri pada Semester I Tahun Pelajaran 2014-2015 dalam menyusun Rencana Pelaksanaan Pembelajara, dan 2) kemampuan guru sekolah dasar Binaan Suraseranggen Unit Pelayanan Teknis (UPT) Dinas Pendidikan Kecamatan Slogohimo Kabupaten Wonogiri pada Semester I Tahun Pelajaran 20142015 dalam menyusun Rencana Pelaksanaan Pembelajaran. Data yang digunakan sebagai sumber dalam Penelitian ini diperoleh dari subjek penelitian dan bukan subjek penelitian. Sumber data dari subjek penelitian merupakan data primer yang diperoleh dari data supervisi penilaian kinerja guru sedangkan sumber data yang berasal dari bukan subjek penelitian merupakan data sekunder diperoleh dari data hasil pengamatan teman sejawat, data hasil wawancara dengan kolabor, dan dokumentasi yang ada.

Teknik pengumpulan data dalam penelitian ini yaitu tes, observasi, dan dokumentasi. Tes yang digunakan dalam penelitian ini merupakan penugasan berupa tes tertulis, selain itu metode pengumpulan data dilaksanakan dengan menggunakan informasi yang diperoleh secara langsung dengan responden pada guru yang bersangkutan. Observasi adalah metode atau cara-cara yang menganalisis dan mengadakan pencatatan secara sistimatis mengenai tingkah laku dengan melihat atau mengamati individu atau kelompok secara langsung (WawanJunaidi). Pada penelitian ini yang diamati tindakan peneliti dalam melakukan supervisi akademik oleh teman sejawat yaitu Drs. Parwianto, M.Pd. juga seorang pengawas sekantor dengan peneliti.

Teknik analisis data dalam penelitian ini menggunakan analisis deskriptif komparatif, dengan cara membandingkan minat dan kemampuan guru dalam menyusun Rencana Pelaksanaan Pembelajaran, antara kondisi awal dengan siklus pertama. Membandingkan minat dan kemampuan guru menyusun Rencana Pelaksanaan Pembelajaran, antara kondisi siklus pertama dengan kondisi siklus II. Membandinngkan minat dan kemampuan guru menyusun Rencana Pelaksanaan Pembelajaran, antara kondisi siklus II dengan kondisi awal. Selanjutnya, indikator keberhasilan Penelitian Tindakan Sekolah ini, diharapkan pada siklus II terjadi peningkatan rata-rata nilai minat sebesar $50 \%$ dari kondisi awal. Kemampuan guru menyusun Rencana Pelaksanaan Pembelajaran yang pada kondisi awal nilai rata-rata termasuk kategori cukup, dapat meningkat menjadi klasifikasi baik dengan nilai rata-rata 70 dari jumlah guru guru sekolah dasar Binaan Suraseranggen Unit Pelayanan Teknis (UPT) Dinas Pendidikan Kecamatan Slogohimo Kabupaten Wonogiri. Berikutnya, prosedur penelitian ini dilaksanakan dua siklus yaitu siklus pertama minat dan kemampuan guru menyusun Rencana Pelaksanaan Pembelajaran dengan tindakan pembinaan 
akademik secara kelompok. Siklus II minat dan kemampuan guru menyusun Rencana Pelaksanaan Pembelajaran dengan tindakan pembinaan akademik secara individual.

\section{HASIL PENELITIAN DAN PEMBAHASAN Hasil Penelitian Kondisi Awal}

Pada kondisi awal sebelum peneliti memberikan tindakan supervise akademik, peneliti melakukan pengukuran terhadap minat dan kemampuan menyusun Rencana Pelaksanaan Pembelajaran, di tempat penelitian. Minat dan kemampuan menyusun Rencana Pelaksanaan Pembelajaran kondisi awal tersebut dapat disajikan dalam tabel sebagai berikut :

\section{Tabel 1. Minat dan kemampuan menyusun RPP}

\begin{tabular}{|c|c|c|c|c|c|c|}
\hline \multirow[b]{2}{*}{ No } & \multirow[b]{2}{*}{ Nama Guru } & \multirow[b]{2}{*}{ SD } & \multirow{2}{*}{$\begin{array}{c}\text { Gr. } \\
\text { Kls }\end{array}$} & \multicolumn{3}{|c|}{ Nilai } \\
\hline & & & & Minat & $\begin{array}{c}\text { Kema } \\
\text { mp }\end{array}$ & Ket \\
\hline 1. & YUNIATI, A.Ma & SDN 3 Randusari & 5 & 41,67 & 54,00 & \\
\hline 2. & SUPANTO, A. Ma & SDN 3 Randusari & 6 & 38,33 & 44,80 & \\
\hline 3. & Danang Anggoro, S.Pd. & SDN 2 Setren & 5 & 46,67 & 58,40 & \\
\hline 4. & Wisnu Jatmiko, S.E & SDN 2 Setren & 6 & 36,67 & 60,00 & \\
\hline 5. & Eka Kurniawati, S.Pd. & SDN 1 Sokoboyo & 5 & 39,17 & 57,60 & \\
\hline 6. & Hartini & SDN 1 Sokoboyo & 6 & 45,00 & 60,80 & \\
\hline 7. & Suyati & SDN 2 Randusari & 5 & 45,83 & 57,00 & \\
\hline 8. & Catur Iriani, S.Pd. & SDN 2 Randusari & 6 & 42,50 & 52,00 & \\
\hline 9. & Nuri Wulandari & SDN 1 Randusari & 5 & 34,17 & 51,20 & \\
\hline 10. & Yulian Pamungkas & SDN 1 Randusari & 6 & 33,33 & 61,00 & \\
\hline 11. & UMI NURJANAH, S.Pd. & SDN 1 Karang & 5 & 35,83 & 81,00 & \\
\hline 12. & SUNARTO, A.Ma.Pd. & SDN 1 Karang & 6 & 36,67 & 55,00 & \\
\hline 13. & Ismiyanto, SPd.SD & SDN 2 Karang & 5 & 37,50 & 49,60 & \\
\hline 14. & Purwanti,SPd.SD. & SDN 2 Karang & 6 & 38,33 & 53,60 & \\
\hline 15. & Sumarno,S.Pd. & SDN 1 Setren & 5 & 35,00 & 55,20 & \\
\hline 16. & Apriana Siam Ndini,S.Pd & SDN 1 Setren & 6 & 26,67 & 57,60 & \\
\hline 17. & Rahmat Wahyudi,S.Pd. & SDN 2 Sokoboyo & 5 & 27,50 & 59,20 & \\
\hline 18. & Agus Purwadi,S.Pd. & SDN 2 Sokoboyo & 6 & 25,00 & 53,60 & \\
\hline 19. & WAHYUNI,S.Pd. & SDN 1 Klunggen & 5 & 25,83 & 54,00 & \\
\hline 20. & SRI HANDAYANI,S.Pd & SDN 1 Klunggen & 6 & 40,83 & 57,60 & \\
\hline & \multicolumn{3}{|l|}{ Nilai Rata-rata } & 36,83 & 56,66 & \\
\hline & \multicolumn{3}{|l|}{ Nilai Tertinggi } & 50,00 & 81,00 & \\
\hline & \multicolumn{3}{|l|}{ Nilai Terendah } & 25,00 & 44,80 & \\
\hline
\end{tabular}

Mengacu pada tabel tersebut, dapat dikemukakan bahwa Minat dan kemampuan menyusun RPP di Sekolah Dasar Binaan Suraseranggen Unit Pelayanan Teknis (UPT) Dinas Pendidikan Kecamatan Slogohimo Kabupaten Wonogiri Semester 1 Tahun Pelajaran 2014/2015 masih rendah, yaitu berada pada kategori cukup. Nilai minat rata-ratanya hanya 36,83 sedangkan nilai kemampuan rataratanya hanya 56,66 termasuk kategori cukup, karena diskripsi rentangan nilai cukup berkisar antara 55,00 s.d. 69,99. Nilai tersebut diperoleh dari penilaian kondisi awal dengan menggunakan instrumen penilaian minat dan kemampuan guru menyusun Rencana Pelaksanaan Pembelajaran. Berdasarkan hasil pada kondisi awal, maka perlu adanya tindakan pada siklus I.

\section{Pelaksanaan Tindakan Siklus I}

Pada siklus I, peneliti melaksanakan tindakan berupa supervisi akademik untuk meningkatkan kemampuan dan minat guru dalam menyusun RPP. Berikut adalah hasil tindakan pada siklus I :

Tabel 2. Nilai Minat dan Kemampuan Guru Menyusun RPP Siklus I

\begin{tabular}{|c|c|c|c|c|c|c|}
\hline \multirow[b]{2}{*}{ No } & \multirow[b]{2}{*}{ Nama Guru } & \multirow[b]{2}{*}{ SD } & \multirow{2}{*}{$\begin{array}{l}\text { Gr. } \\
\text { Kls }\end{array}$} & \multicolumn{3}{|c|}{ Nilai } \\
\hline & & & & Minat & $\begin{array}{c}\text { Kemam } \\
\text { puan }\end{array}$ & Ket \\
\hline 1. & YUNIATI, A.Ma & SDN 3 Randusari & 5 & 45,67 & 54,00 & \\
\hline 2. & SUPANTO, A. Ma & SDN 3 Randusari & 6 & 55,00 & 44,80 & \\
\hline 3. & Danang Anggoro, S.Pd. & SDN 2 Setren & 5 & 54,17 & 58,40 & \\
\hline 4. & Wisnu Jatmiko, S.E & SDN 2 Setren & 6 & 46,67 & 60,00 & \\
\hline 5. & Eka Kurniawati, S.Pd. & SDN 1 Sokoboyo & 5 & 46,67 & 57,60 & \\
\hline 6. & Hartini & SDN 1 Sokoboyo & 6 & 55,83 & 60,80 & \\
\hline 7. & Suyati & SDN 2 Randusari & 5 & 65,00 & 57,00 & \\
\hline 8. & Catur Iriani, S.Pd. & SDN 2 Randusari & 6 & 55,00 & 52,00 & \\
\hline 9. & NuriWulandari & SDN 1 Randusari & 5 & 46,67 & 51,20 & \\
\hline 10. & Yulian Pamungkas & SDN 1 Randusari & 6 & 55,00 & 61,00 & \\
\hline 11. & UMI NURJANAH, S.Pd. & SDN1 Karang & 5 & 63,33 & 81,00 & \\
\hline 12. & SUNARTO, A.Ma.Pd. & SDN 1 Karang & 6 & 46,67 & 55,00 & \\
\hline 13. & Ismiyanto, SPd.SD & SDN 2 Karang & 5 & 54,17 & 49,60 & \\
\hline 14. & Purwanti,SPd.SD. & SDN2 Karang & 6 & 55,00 & 53,60 & \\
\hline 15. & Sumarno,S.Pd. & SDN 1 Setren & 5 & 63,33 & 55,20 & \\
\hline 16. & $\begin{array}{l}\text { Apriana Siam } \\
\qquad \text { Ndini,S.Pd }\end{array}$ & SDN 1 Setren & 6 & 45,83 & 57,60 & \\
\hline 17. & Rahmat Wahyudi,S.Pd. & SDN 2 Sokoboyo & 5 & 44,17 & 59,20 & \\
\hline 18. & Agus Purwadi,S.Pd. & SDN2 Sokoboyo & 6 & 53,33 & 53,60 & \\
\hline 19. & WAHYUNI,S.Pd. & SDN1 Klunggen & 5 & 38,33 & 54,00 & \\
\hline 20. & SRIHANDAYANI,S.Pd & SDN1 Klunggen & 6 & 63,33 & 57,60 & \\
\hline & Nilai Rata-rata & & & 52,88 & 56,66 & \\
\hline & Nilai Tertinggi & & & 65,00 & 81,00 & \\
\hline & Nilai Terendah & & & 38,33 & 44,80 & \\
\hline
\end{tabular}

Mengacu pada tabel tersebut diperoleh keterangan bahwa minat menyusun Rencana Pelaksanaan Pembelajaran nilai rata-ratanya meningkat 
sebesar $16,04 \%$ yaitu dari 36,83 menjadi rata-rata 52,88 Nilai terendah mengalami perubahan $13,33 \%$ dari 25,00 menjadi 38,33. Nilai tertinggi meningkat $15,00 \%$ yaitu dari 50,00 menjadi 65,00. Selanjutnya kemampuan guru menyusun RPP di tempat penelitian untuk menyusun Rencana Pelaksanaan Pembelajaran nilai rataratanya meningkat sebesar $22,72 \%$ yaitu dari 56,66 menjadi rata-rata 79,38. Nilai terendah mengalami perubahan $29,62 \%$ dari 44,80 menjadi 74,40 . Nilai tertinggi meningkat $2,20 \%$ yaitu dari 81,00 menjadi 83,20 . Dengan demikian pelaksanaan supervisi akademik yang dilakukan Pengawas belum mampu meningkatkan minat serta kemampuan guru menyusun Rencana Pelaksanaan Pembelajaran kepada setiap guru. Oleh karena itu perlu dilanjutkan pemberian tindakan pada siklus II.

\section{Pelaksanaan Tindakan Siklus II}

Pada siklus II, peneliti kembali melakukan tindakan supervise akademik sebagai bentuk perbaikan dari tindakan pada siklus I. Hasil dari pelaksanaan tindakan pada siklus II adalah sebagai berikut :

Tabel 3. Nilai Minat dan Kemampuan Guru Menyusun RPP Siklus II

\begin{tabular}{|c|c|c|c|c|c|c|}
\hline \multirow{2}{*}{ No } & \multirow{2}{*}{ Nama Guru } & \multirow{2}{*}{ SD } & \multirow{2}{*}{$\begin{array}{l}\text { Gr. } \\
\text { Kls }\end{array}$} & \multicolumn{3}{|c|}{ Nilai } \\
\hline & & & & Minat & $\begin{array}{l}\text { Kema } \\
\text { mpua }\end{array}$ & Ket \\
\hline 1. & Yuniati, A.Ma & SDN 3 Randusari & 5 & 51,67 & 60,13 & \\
\hline 2. & Supanto, A. Ma & SDN 3 Randusari & 6 & 54,17 & 38,33 & \\
\hline 3. & Danang Anggoro, S.Pd. & SDN 2 Setren & 5 & 56,67 & 75,00 & \\
\hline 4. & Wisnu Jatmiko, S.E & SDN 2 Setren & 6 & 58,33 & 76,00 & \\
\hline 5. & Eka Kurniawati, S.Pd. & SDN 1 Sokoboyo & 5 & 62,50 & 80,00 & \\
\hline 6. & Hartini & SDN 1 Sokoboyo & 6 & 62,50 & 82,40 & \\
\hline 7. & Suyati & SDN 2 Randusari & 5 & 64,17 & 80,00 & \\
\hline 8. & Catur Iriani, S.Pd. & SDN 2 Randusari & 6 & 66,67 & 83,20 & \\
\hline 9. & Nuri Wulandari & SDN 1 Randusari & 5 & 70,83 & 81,60 & \\
\hline 10. & Yulian Pamungkas & SDN 1 Randusari & 6 & 73,33 & 81,60 & \\
\hline 11. & Umi Nurjanah, S.Pd. & SDN 1 Karang & 5 & 75,00 & 80,00 & \\
\hline 12. & Sunarto, A.Ma.Pd. & SDN 1 Karang & 6 & 72,50 & 78,40 & \\
\hline 13. & Ismiyanto, SPd.SD & SDN 2 Karang & 5 & 58,33 & 82,00 & \\
\hline 14. & Purwanti,SPd.SD. & SDN 2 Karang & 6 & 62,50 & 81,60 & \\
\hline 15. & Sumarno,S.Pd. & SDN 1 Setren & 5 & 65,83 & 74,40 & \\
\hline 16. & Apriana Siam Ndini,S.Pd & SDN 1 Setren & 6 & 45,83 & 77,60 & \\
\hline 17. & Rahmat Wahyudi,S.Pd. & SDN 2 Sokoboyo & 5 & 50,00 & 80,80 & \\
\hline 18. & Agus Purwadi,S.Pd. & SDN 2 Sokoboyo & 6 & 50,00 & 76,80 & \\
\hline 19. & Wahyuni,S.Pd. & SDN 1 Klunggen & 5 & 38,33 & 74,40 & \\
\hline \multirow[t]{4}{*}{20.} & Sri Handayani,S.Pd & SDN 1 Klunggen & 6 & 63,33 & 77,60 & \\
\hline & \multicolumn{3}{|l|}{ Nilai Rata-rata } & 60,13 & 79,38 & \\
\hline & \multicolumn{3}{|l|}{ Nilai Tertinggi } & 75,00 & 83,20 & \\
\hline & \multicolumn{3}{|l|}{ Nilai Terendah } & 38,33 & 74,40 & \\
\hline
\end{tabular}

Mengacu pada tabel tersebut diperoleh keterangan bahwa Minat guru untuk menyusun Rencana Pelaksanaan Pembelajaran nilai rata-ratanya meningkat sebesar 13,85 \% yaitu dari 55.94 menjadi menjadi 63,69 . Nilai terendah meningkat $16,82 \%$ yaitu dari 42,80 menjadi 50,00. Sedangkan nilai tertinggi meningkat $11,10 \%$ yaitu dari 64,28 menjadi 71,42 . Selanjutnya, kemampuan guru dalam menyusun RPP nilai rata-ratanya meningkat sebesar $11,47 \%$ yaitu dari 59,47 menjadi 66,29. Nilai tertinggi meningkat $17,25 \%$. Sedangkan nilai terendah meningkat $18,18 \%$ yaitu dari 50 menjadi 59,09. Berdasarkan hasil tersebut maka dapat disimpulkan bahwa pelaksanaan supervisi akademik yang dilakukan peneliti sudah mampu meningkatkan minat serta kemampuan guru menyusun Rencana Pelaksanaan Pembelajaran kepada setiap guru. Oleh karena itu tidak perlu dilanjutkan pemberian tindakan pada siklus berikutnya.

\section{Pembahasan}

Pada kondisi awal minat dan kemampuan menyusun Rencana Pelaksanaan Pembelajaran guru di Sekolah Dasar Binaan Suraseranggen Unit Pelayanan Teknis (UPT) Dinas Pendidikan Kecamatan Slogohimo Kabupaten Wonogiri Semester 1 Tahun Pelajaran 2014/2015 belum termasuk kategori baik dikarenakan memang belum terprogramnya supervisi oleh Pengawas. Kurangnya kesadaran guru tentang manfaat Rencana Pelaksanaan Pembelajaran dalam kegiatan belajar mengajar. Banyaknya biro jasa penyedia pembuatan Rencana Pelaksanaan Pembelajaran yang dijual bebas dengan berbagai macam jenis, sehingga menyebabkan guru semakin enggan untuk menyusun Rencana Pelaksanaan Pembelajaran sendiri. 
Pelaksanaan supervisi akademik yang dilakukan Pengawas kepada di Sekolah Dasar Binaan SURASERANGGEN Unit Pelayanan Teknis (UPT) Dinas Pendidikan Kecamatan Slogohimo Kabupaten Wonogiri Semester 1 Tahun Pelajaran 2013/2014 dari kondisi awal sampai siklus II terdapat peningkatan. Peningkatan minat dari kondisi awal kekondisi akhir hanya 24,30\%. Peningkatan itu belum dapat dikatakan berhasil jika diukur dari indikator kinerja yang seharusnya terjadi peningkatan minat sebesar $50 \%$. Sedangkan kemampuan menyusun Rencana Pelaksanaan Pembelajaran bagi di Sekolah Dasar Binaan SURASERANGGEN Unit Pelayanan Teknis (UPT) Dinas Pendidikan Kecamatan Slogohimo Kabupaten Wonogiri Semester 1 Tahun Pelajaran 2013/2014 juga terjadi peningkatan. Peningkatan kemampuan membuat Rencana Pelaksanaan Pembelajaran dari kondisi awal sampai kondisi siklus II sebesar 22,72 \% dengan rata-rata 74,40 termasuk kategori baik. Kenaikan ini juga sudah dapat dikatakan berhasil jika diukur dari indikator kinerja yang seharusnya kategori baik dengan rata-rata nilai 70,00 .

Pelaksanaan supervisi akademik yang dilakukan Pengawas sudah mampu meningkatkan minat dan kemampuan guru di Sekolah Dasar Binaan Suraseranggen Unit Pelayanan Teknis (UPT) Dinas Pendidikan Kecamatan Slogohimo Kabupaten Wonogiri Semester 1 Tahun Pelajaran 2014/2015 dalam menyusun Rencana Pelaksanaan Pembelajaran, sesuai dengan indikator kinerja yang telah ditetapkan.

\section{KESIMPULAN}

Kesimpulan dari hasil penelitian ini yaitu Supervisi Akademik mampu meningkatkan minat dan kemampuan guru dalam membuat Rencana Pelaksanaan Pembelajaran pada Guru Sekolah Dasar Binaan Suraseranggen Unit Pelayanan Teknis (UPT) Dinas Pendidikan Kecamatan Slogohimo Kabupaten Wonogiri Semester 1 Tahun Pelajaran 2014/2015.

\section{DAFTAR PUSTAKA}

Aiken, Lewis R. 1994. Psychologycal Testing and Assessment. MA Allyn and Bacon.

Arikunto, Suharsimi. 1993. Prosedur Penelitian Suatu Pendekatan Praktek. Jakarta: Rineka Cipta

Chaplin, J. P. 2000. Dictionary of Psychology. New York: Dell Publishing Co. Inc.

Crow. L. D., A. Crow. 1963. An Outline of General Psychology. NewJersey: Littlefield Adams \& Co.

Departemen Pendidukan Nasional. (2006). Panduan Kurikulum Satuan Tingkat Pendidikan (KTSP ) SD/MI. Jakarta : Depdiknas.

Dimyati Mahmud. (1982). Strategi Belajar Mengajar. Jakarta: Departemen Pendidikan Nasional

Enoch Markum. 1983. Anak, Keluarga, dan Masyarakat. Jakarta: Sinar Harapan.

Glickman.CD. (2007) Developmental Supervision. Alternative Practice HelpingTeachers Improve Instruction. Virginia.Alexandria:ASCD

http://id.wikipedia.org/wiki/Efek_rumah_kaca diakses tanggal 4 Mei 2015

http://www.unika.ac.id/fakultas/psikologi/artikel/ss.i.pdf diakses 13 Juli 2015.

Hurlock, E. B. 1983. Child Development. New Delhi: Mcgraw-Hill.

Istiwiyanto Sujarwo. 1991. Psikologi Perkembangan Suatu Pendidikan Sepanjang Kehidupan. Terjemahan. Child Development. Jakarta: Erlangga. 
Istiwiyanto Sujarwo. 1991. Psikologi Perkembangan Suatu Pendidikan Sepanjang Kehidupan. Terjemahan. Child Development. Jakarta: Erlangga.

Meitasari Candrasa. 1990. Membina Hasrat Belajar di Sekolah. Bandung: Remaja Karya.

Nurgiansah, T. H., \& Pringgowijoyo, Y. (2020). Pelatihan Penggunaan Model Pembelajaran Jurisprudensial Pada Guru Di KB TK Surya Marta Yogyakarta. KUAT: Keuangan Umum Dan Akuntansi Terapan. PKNSTAN, 2(1).

Oteng Sutisna. Asas-Asas Supervisi Pengajaran.1985. Bandung: Jurusan Administrasi Pendidikan FIP-IKIP Bandung

Peraturan Pemerintah No.19 Tahun 2005 Tentang Standar Nasional Pendidikan. Jakarta: Depdiknas.

Peraturan Pemerintah Republik Indonesia Nomor 19 Tahun 2005 Standar Nasional Pendidikan. 16 Mei 2005. Lembaran Negara Republik Indonesia Tahun 2005 Nomor 41. Jakarta

Permedikas RI nomor 41 tahun 2007 Tentang Standar Proses Untuk Satuan Pendidikan Dasar Dan Menengah

Standar Kompetensi dan Kompetensi Dasar Mata Pelajaran:Jakarta BSNP 2006 Rineka Cipta

Thomas J. Sergiovanni \& Robert J. Sttaratt. Supervision:Human perspectives,New York: McGraw-Hill (1993:45)

Undang-Undang Republik Indonesia No. 20 Tahun 2003 Tentang Sistem Pendidikan Nasional. Jakarta: Depdiknas. 